\title{
Oxidative stress in patients with type 2 diabetes mellitus treated with metformin
}

\author{
Estresse oxidativo em pacientes com diabetes mellitus tipo 2 em tratamento \\ com metformina
}

\author{
Samuel Selbach Dries ${ }^{1}$, Barbara da Silveira Soares ${ }^{2}$, Simone Gasparin Verza ${ }^{3}$, Ana Luiza Ziulkoski ${ }^{3}$, Rafael Linden $^{3}$, \\ Fabiana Michelsen de Andrade ${ }^{4}$, Magda Susana Perassolo ${ }^{3} \bowtie$ \\ ${ }^{1}$ Fundação Hospital Municipal Schlatter. Feliz, RS. \\ 2 Unidade de Saúde da Família Petrópolis. Novo Hamburgo, RS. \\ ${ }^{3}$ Curso de Farmácia da Universidade Feevale. Novo Hamburgo, RS \\ ${ }^{4}$ Curso de Medicina Veterinária do Centro Universitário Ritter dos Reis. Porto Alegre, RS.
}

\section{ABSTRACT}

AIMS: To evaluate oxidative stress parameters in patients with type 2 diabetes mellitus treated with metformin, relating these values to its side effects, plasma levels, glycemic control, diabetic complications, lipid profile, and the influence of pharmacotherapeutic follow-up.

METHODS: Patients with type 2 diabetes mellitus, on metformin and in pharmacotherapeutic follow-up for four months, were evaluated. The pharmacotherapeutic follow-up consisted in providing information and answering patients' questions about medication and disease. In addition, administration times, dosages, and presence or absence of side effects related to the use of metformin were verified. Glycemic and lipid profile, oxidative stress (superoxide dismutase and malondialdehyde) and plasma metformin were evaluated. Pearson's correlation and Spearman's correlation were performed to evaluate the relationship between the variables at the beginning of the study. The independent t-test and Mann-Whitney $U$ test were used to assess the difference between the groups with and without diabetic complications. The range of values between the beginning and end of the study was evaluated using Student's t-test or Wilcoxon U test. The significance level was set at 5\%.

RESULTS: The initial sample consisted of 49 patients aged $59 \pm 9$ years with a body mass index of $29.8 \pm 5.1 \mathrm{~kg} / \mathrm{m}^{2}$, who have had diabetes for a median time of 36 months (interquartile range of 1-240) and have been on metformin for a median time of 36 months (interquartile range of 1-180). Twenty-five patients left the study between the second and fourth meetings. Malondialdehyde levels differed between before and after pharmacotherapeutic follow-up, being positively correlated with blood glucose, glycohemoglobin, and triglyceride level, and negatively correlated with metformin and superoxide dismutase. Blood glucose, glycohemoglobin, and malondialdehyde levels increased, whereas metformin levels decreased in the group with diabetic complications, and there was a correlation between malondialdehyde and the number of diabetic complications per patient.

CONCLUSIONS: In this sample of patients with type 2 diabetes mellitus treated with metformin, oxidative stress was more pronounced in those with poor glycemic control and diabetic complications.

KEY WORDS: diabetes mellitus; oxidative stress; superoxide dismutase; malondialdehyde; metformin; diabetic complications.

\section{RESUMO}

OBJETIVOS: Avaliar parâmetros de estresse oxidativo em pacientes com diabetes mellitus tipo 2 em uso de metformina, relacionando estes valores a seus efeitos adversos, níveis plasmáticos, controle glicêmico, complicações diabéticas, perfil lipídico, e a influência do acompanhamento farmacoterapêutico.

MÉTODOS: Foram avaliados pacientes com diabetes mellitus tipo 2, em uso de metformina, em acompanhamento farmacoterapêutico por quatro meses. $\mathrm{O}$ acompanhamento farmacoterapêutico consistiu na prestação de informações e no esclarecimento de dúvidas dos pacientes sobre a medicação e a doença. Além disto, foram verificados os horários, as doses e a presença ou não de efeitos adversos relacionados ao uso de metformina. Foram avaliados perfil glicêmico e lipídico, estresse oxidativo (superóxido dismutase e malondialdeído) e metformina plasmática. Foram realizados os testes de correlação de Pearson e de Spearman para avaliar as relações entre as variáveis no início do estudo. Para testar a diferença entre os grupos com e sem complicações diabéticas, foram utilizados o t-teste independente ou o teste U de MannWhitney. A gama de valores entre o início e o final do estudo foi avaliada utilizando o teste t de Student ou o teste de Wilcoxon U. Foi adotado um nível de significância de 5\%.

RESULTADOS: A amostra inicial foi composta por 49 pacientes com idade de $59 \pm 9$ anos e índice de massa corporal de $29,8 \pm 5,1 \mathrm{~kg} / \mathrm{m}^{2}, \mathrm{com}$ diabetes por uma mediana de tempo de 36 (intervalo interquartil 1-240) meses e em uso de metformina há uma mediana de 36 (intervalo interquartil 1-180) meses. Vinte e cinco pacientes deixaram o estudo entre a segunda e a quarta reunião. Os níveis de malondialdeído diferiram entre antes e após o acompanhamento farmacoterapêutico, correlacionando-se positivamente com glicemia, glicohemoglobina e triglicerídeos e negativamente com metformina e superóxido dismutase. Encontrou-se elevação da glicemia, glicohemoglobina e malondialdeído, e diminuição da metformina no grupo com complicações diabéticas, e foi identificada correlação entre malondialdeído e o número de complicações diabéticas por paciente.

CONCLUSÕES: Nesta amostra de pacientes com diabetes mellitus tipo 2 em tratamento com metformina, o estresse oxidativo foi mais pronunciado nos que apresentavam pior controle glicêmico e complicações diabéticas.

DESCRITORES: diabetes mellitus; estresse oxidativo; superóxido dismutase; malondialdeído; metformina; complicações do diabetes.

Received: November, 2016

Accepted: April, 2017

Published: May, 2017 
Abbreviations: BLOS, blood oxidative stress; BMI, body mass index; DM, diabetes mellitus; DM1, type 1 diabetes mellitus; DM2, type 2 diabetes mellitus; HbA1c, glycohemoglobin; LPO, lipid peroxidation; MDA, malondialdehyde; PF, pharmacotherapeutic follow-up; ROS, reactive oxygen species; SOD, superoxide dismutase; TC, total cholesterol; TG, triglycerides.

\section{INTRODUCTION}

Diabetes mellitus (DM) is a syndrome caused by metabolic disorders due to impaired insulin action and/or secretion, and it is characterized by chronic hyperglycemia [1]. DM is one of the most common chronic diseases in the world, and its incidence has increased considerably, especially in developing countries such as Brazil [2]. DM accounts for over 77\% of morbidity and $88 \%$ mortality in low- and middleincome countries, killing 4.6 million people worldwide only in 2013 [3]. In the same year, it was estimated that there were 11,933,580 people aged 20-79 years with diabetes in Brazil [1] and 382 million people living with diabetes worldwide, and these numbers are likely to increase by $155 \%$ by 2035 . Thus, it is estimated that among 10 people living in the world in 2035, one will be diabetic [4].

The current DM classification is based on the etiology of the disease and includes four clinical classes: DM type 1 (DM1), DM type 2 (DM2), other specific types of DM, and gestational DM. DM1 and DM2 are the two most prevalent clinical classes. DM1 is characterized by destruction of pancreatic beta cells, leading to insulin deficiency. On the other hand, DM2 is characterized by defects in insulin action and secretion and in the regulation of hepatic glucose production, being caused by an interaction of genetic and environmental factors [1].

Studies have reported the existence of a strong correlation between hyperglycemia and the presence of microvascular complications $[5,6]$, for example, retinopathy $[7,8]$, nephropathy $[8,9]$, and diabetic neuropathy [10]. Macrovascular complications [5, 11], which represent the leading cause of death in DM2 [7, 12], have been associated with poor glycemic control [13] and blood oxidative stress (BLOS) [14]. This happens because of the induction of superoxide release due to changes in the electron transport chain of mitochondria [15] and increased activity of NADPH oxidase [14]. Metformin is considered the primary drug for treating DM2 [1]; it apparently acts on the mechanisms described above, thus having a pronounced antioxidant effect [16].
Some products are formed continuously during cellular metabolic processes, for instance, the reactive oxygen species (ROS), which are atoms, ions, or molecules that have an unpaired electron in their outer orbital. For this reason, they are highly reactive, tending to connect to nearby structures $[17$, 18]. Superoxide dismutase (SOD) is an enzyme that catalyzes the dismutation of the superoxide anion $\left(\mathrm{O}_{2}^{-}\right)$into oxygen $\left(\mathrm{O}_{2}\right)$ and hydrogen peroxide $\left(\mathrm{H}_{2} \mathrm{O}_{2}\right)$, whose predominant isoform in the extracellular environment is EC-SOD (SOD3) [19]. Ookawara et al. [20] demonstrated that SOD3 is also present in the intracellular environment and that its heparin-binding site can act as a nuclear localization signal, allowing it to be directed to the nucleus, thus being involved in the mechanism of protection against oxidative damage to the DNA.

Lipid peroxidation (LPO) is a biochemical reaction due to ROS action on the cell membranes, which leads to serious structural damage, failure of metabolite exchange mechanisms, and under extreme conditions, cell death $[21,22]$. Malondialdehyde (MDA) is one of the LPO products. Marnett [23] studied its genotoxicity and demonstrated its ability to interact with nucleic acid bases. These adducts are able to induce mutations that cause errors in the reading phase and base-pair substitutions in bacterial and mammalian cells.

Despite the existing knowledge regarding the functions of these molecules in the human body, few studies have evaluated their correlations in metformintreated DM2 patients and possible associations with the treatment. Hence, the objective of this study was to evaluate oxidative stress parameters in DM2 patients on metformin therapy, relating these values with the side effects of this medication, plasma levels, glycemic control, diabetic complications, lipid profile, and the influence of pharmacotherapeutic follow-up on patients' biochemical parameters.

\section{METHODS}

This study was approved by the Research Ethics Committee of Feevale University (process number 2.02.01.07.608). All participants signed a consent form in duplicate and received one of the copies before the procedures.

The study group consisted of DM2 patients on metformin monotherapy from the Vale do Sinos region and the Metropolitan Area of Porto Alegre, state of Rio Grande do Sul, Brazil, treated between 2010 and 2013.

Inclusion criteria were as follows: diagnosis of DM2; age between 35 and 75 years; and previous 
treatment with metformin. The following exclusion criteria were used: diagnosis of DM1 or another type of diabetes besides DM2; use of insulin or sulfonylurea; use of hormone replacement therapy; body mass index (BMI) above $40 \mathrm{~kg} / \mathrm{m}^{2}$; diseases related to malabsorption (food and/or medicines); acute or chronic pancreatitis; kidney or liver disease (or history of hepatitis); aids; creatinine levels above $1.5 \mathrm{mg} / \mathrm{dL}$; history of alcohol or drug abuse; pregnancy; and lactation.

Subsequently to the approval by the Research Ethics Committee, we started the selection of patients by analyzing records and registration forms at the health clinics of Feevale University. After this initial screening, patients participated in a scheduled interview in order to complete the checklist for inclusion and exclusion criteria. The individuals who met the inclusion criteria signed a free and informed consent form and, subsequently, answered a brief questionnaire about their pathological condition and drug treatment. Blood was collected for laboratory analysis.

Patients included in the study had a four-month follow-up, with monthly meetings, following the schedule described in Chart 1. The pharmacotherapeutic follow-up consisted in providing information and answering patients' questions about medication and disease. In addition, administration times, dosages, and presence or absence of side effects of metformin were verified.

Chart 1. Procedures adopted in the follow-up of patients

\begin{tabular}{|c|c|}
\hline Scheduled visit & \multicolumn{1}{c|}{ Procedures } \\
Month 0 & $\begin{array}{c}\text { - Verification of the inclusion criteria; signature } \\
\text { of the Free and Informed Consent Form; data } \\
\text { collection (questionnaires); PF. }\end{array}$ \\
Month 1 & $\begin{array}{c}\text { - PF; blood collection for dosages: fasting blood } \\
\text { glucose, HbA1c, cholesterol, triglycerides, HDL, } \\
\text { LDL, MDA, SOD, and plasma metformin. }\end{array}$ \\
Month 2 & - PF; glucose monitoring with BGT. \\
\hline Month 3 & - PF; glucose monitoring with BGT. \\
Month 4 & $\begin{array}{c}- \text { PF; blood collection for dosages: fasting blood } \\
\text { glucose, HbA1c, cholesterol, triglycerides, HDL, } \\
\text { LDL, MDA, SOD, and plasma metformin. }\end{array}$ \\
\hline
\end{tabular}

PF, pharmacotherapeutic follow-up; HbA1c, glycohemoglobin; HDL, high-density lipoprotein; LDL, low-density lipoprotein; MDA, malondialdehyde; SOD, superoxide dismutase; BGT, blood glucose test.

After blood collection, the biological material was placed in proper collection tubes, stored in a cooler, and transported to the laboratories for lipid profile, fasting plasma glucose, and glycohemoglobin (HbA1c) measurements. Part of the material was centrifuged, and the plasma was transferred into properly labeled polypropylene tubes and stored in a freezer at $-80{ }^{\circ} \mathrm{C}$ until completion of SOD, MDA, and plasma metformin dosages.

Extracellular SOD activity was determined by inhibition of epinephrine autoxidation. The sample was diluted in $0.9 \% \mathrm{NaCl}$, and then glycine buffer, catalase, and epinephrine were added. Five readings were obtained at $480 \mathrm{~nm}$ from a kinetic spectrophotometer (Varian Cary 50) at different concentrations after 180 seconds of irradiation time. SOD plasma concentration was calculated from the data obtained and by linear regression analysis. The obtained values were corrected by the amount of total plasma protein, which was dosed using a commercial kit (Labtest), and the result was expressed in SOD units/g of protein.

According to the method described by Antunes et al. [24], MDA dosages were initiated with alkaline hydrolysis of plasma in order to release the proteinbound fraction, subsequently precipitated by the addition of $\mathrm{HClO}_{4}$. DNPH-derivatized protein was added to the supernatant. Chromatographic run was performed in a Shimadzu Class VP HPLC diode array detector with a Lichrospher RP-18 Merck column $(250 \times 4 \mathrm{~mm}, 5 \mu \mathrm{m} \mathrm{di})$. The mobile phase consisted of $0.2 \%$ acetic acid $(\mathrm{w} / \mathrm{v})$ :acetonitrile $(62: 38)$, at a flow rate of $1 \mathrm{~mL} / \mathrm{min}$, and the $310-\mathrm{nm}$ wavelength was used for detection.

In order to determine plasma metformin, blood samples were collected at the trough level (before the first daily dose). Plasma concentration was obtained by HPLC-DAD in a high-efficiency liquid chromatograph (Shimadzu Class VP). The stationary phase consisted of a Shimpack C18 column $(15 \times 4 \mathrm{~mm})$ and the mobile phase consisted of $40 \%$ acetonitrile and $60 \%$ sodium dodecyl sulfate $0.01 \mathrm{M}$ in water, $\mathrm{pH}=5.1$ phosphate buffer $(20 \mathrm{mM})$, at a flow rate of $1 \mathrm{ml} / \mathrm{min}$. Chromatography was monitored at $232 \mathrm{~nm}$.

As for the lipid profile, total cholesterol (TC) parameters and HDL were measured using a commercial kit from Wiener Lab, and triglycerides (TG) using a Labtest kit, while LDL was calculated by the Friedewald formula [LDL $=\mathrm{TC}-\mathrm{HDL}-(\mathrm{TG} / 5)]$. Fasting blood glucose was measured by an enzymatic colorimetric method with a commercial kit from Labtest, and HbA1c was determined by HPLC [25]. The blood glucose test was performed via a finger-stick device using the Accu Check $\mathrm{II}^{\circledR}$ monitoring system.

In the statistical analysis, the normality of the variables was tested, and all tests were performed using the IBM SPSS statistics software, version 22.0, adopting a 5\% significance level. Normally distributed data were expressed as mean \pm standard deviation. 
Those without normal distribution and which could not be normalized through logarithmic transformation were expressed as median and interquartile range (25th percentile- 75 th percentile).

Correlation tests were performed to evaluate the relationship between the variables at the beginning of the study. Parametric variables were assessed by Pearson's correlation and nonparametric ones were assessed by Spearman's correlation. To test the difference between the groups with and without diabetic complications, the independent t-test and Mann-Whitney $U$ test were used for parametric and nonparametric samples, respectively.

The range between initial and end-of-study values (four-month follow-up) was evaluated using Student's t-test for paired samples with normally distributed variables and Wilcoxon $U$ test for those without normal distribution.

\section{RESULTS}

The initial sample consisted of 49 patients aged $59 \pm 9$ years with a BMI of $29.8 \pm 5.1 \mathrm{~kg} / \mathrm{m}^{2}$. Patients had had DM2 for a median time of 36 months (interquartile range 1-240) and had been on metformin for a median time of 36 months (interquartile range 1-180) with a daily dose of $1,700(500-2,550) \mathrm{mg}$.

Out of the 49 patients who started the follow-up, 24 left the study between the second and fourth meetings because they added another hypoglycemic drug to their therapy, and one patient withdrew for personal reasons. In total, 24 patients reached the end of the study.

Changes in MDA levels (3.37 \pm 1.06 vs. $2.40 \pm$ $0.73 \mu \mathrm{M} ; \mathrm{p}<0.001$ ) were only observed when comparing laboratory dosages between the beginning (month 1) and end of the study (month 4). No statistically significant change was found in other dosages (Table 1).

Most patients (76\%) did not report adverse effects associated with metformin. Most of the reported effects were related to the digestive tract, namely: gastric discomfort (8\%), flatulence (8\%), diarrhea (5\%), and nausea $(3 \%)$. No patient reported the occurrence of lactic acidosis.

Of the patients studied, $44 \%$ had no complications related to DM. The main complications reported by patients were nephropathy (26\%), neuropathy (15\%), heart diseases $(12 \%)$, retinopathy $(9 \%)$, and stroke $(6 \%)$.

The laboratory parameters obtained in the first month were compared between patients with and without DM complications. It was observed that patients with complications had higher blood glucose, $\mathrm{HbA1c}$, and MDA levels associated with decreased levels of plasma metformin (Table 2).

The adverse effects of metformin and diabetic complications were correlated with oxidative stress parameters obtained at the beginning of the study, in which a positive correlation between MDA values and the number of diabetic complications in each patient $(r=0.560 ; p=0.001)$ was observed, but not with SOD values $(r=-0.138 ; p=0.510)$. The presence of adverse effects showed no correlation with MDA ( $\mathrm{r}=0.219$; $\mathrm{p}=0.199)$ or with SOD $(\mathrm{r}=-0.220 ; \mathrm{p}=0.281)$.

MDA levels were positively correlated with glycemic control (blood glucose and HbAlc) and triglycerides and negatively correlated with metformin plasma levels.

SOD levels were not correlated with glycemic control and lipid profile, but were negatively correlated with MDA levels $(r=-0.554, p<0.001)$ (Table 3).

Table 1. Comparison of laboratory characteristics of 24 patients with type 2 diabetes mellitus in treatment with metformin, living in the Vale do Sinos region and in the Metropolitan Area of Porto Alegre, state of Rio Grande do Sul, Brazil, between 2010 and 2013, at the beginning and end of a four-month pharmacotherapeutic follow-up.

\begin{tabular}{lccc}
\hline \multicolumn{1}{c}{ Laboratory blood parameters } & Month $\mathbf{1}$ & Month $\mathbf{4}$ & p \\
Blood glucose $(\mathrm{mg} / \mathrm{dL})^{1}$ & $133 \pm 35$ & $120 \pm 18$ & 0.316 \\
HbA1c $(\%)^{1}$ & $7.12 \pm 1.33$ & $6.40 \pm 0.69$ & 0.224 \\
Cholesterol $(\mathrm{mg} / \mathrm{dL})^{1}$ & $194 \pm 54$ & $189 \pm 31$ & 0.869 \\
Triglycerides $(\mathrm{mg} / \mathrm{dL})^{1}$ & $162 \pm 83$ & $144 \pm 57$ & 0.820 \\
HDL $(\mathrm{mg} / \mathrm{dL})^{1}$ & $46 \pm 11$ & $43 \pm 15$ & 0.396 \\
LDL $(\mathrm{mg} / \mathrm{dL})^{1}$ & $113 \pm 41$ & $117 \pm 33$ & 0.361 \\
Plasma metformin $(\mathrm{ng} / \mathrm{mL})^{2}$ & $330(220-495)$ & $594(215-758)$ & 0.069 \\
SOD $(\mathrm{U} / \mathrm{g}$ protein) & $8.90(-29.43-19.17)$ & $8.13(-13.12-17.45)$ & 0.674 \\
MDA $(\mu \mathrm{M})^{1}$ & $3.37 \pm 1.06$ & $2.40 \pm 0.73$ & $<0.001$ \\
\hline
\end{tabular}

HbA1c, glycohemoglobin; HDL, high-density lipoprotein; LDL, low-density lipoprotein; MDA, malondialdehyde; SOD, superoxide dismutase. ${ }^{1}$ mean \pm standard deviation, independent t-test; ${ }^{2}$ median (interquartile range), Mann-Whitney $U$ test. 
Table 2. Comparison of laboratory parameters found in month 1 between patients with type 2 diabetes mellitus on metformin, $(\mathrm{n}=49)$, with and without diabetic complications. Vale do Sinos region and Metropolitan Area of Porto Alegre, state of Rio Grande do Sul, Brazil, 2010-2013.

\begin{tabular}{lccc}
\hline \multicolumn{1}{c}{ Laboratory blood parameters } & $\begin{array}{c}\text { With diabetic complications } \\
(\mathbf{n = 2 7})\end{array}$ & $\begin{array}{c}\text { Without diabetic complications } \\
(\mathbf{n = 2 2})\end{array}$ & $\mathbf{p}$ \\
\hline Blood glucose $(\mathrm{mg} / \mathrm{dL})^{1}$ & $152 \pm 60$ & $119 \pm 18$ & 0.026 \\
\hline HbA1c $(\%)^{2}$ & $7.50(6.72-8.25)$ & $6.12(5.99-7.80)$ & $\mathbf{0 . 0 2 1}$ \\
Cholesterol $(\mathrm{mg} / \mathrm{dL})^{1}$ & $205 \pm 70$ & $178 \pm 36$ & 0.150 \\
\hline Triglycerides $(\mathrm{mg} / \mathrm{dL})^{1}$ & $183 \pm 113$ & $142 \pm 50$ & 0.159 \\
HDL $(\mathrm{mg} / \mathrm{dL})^{1}$ & $49 \pm 11$ & $43 \pm 10$ & 0.151 \\
\hline LDL $(\mathrm{mg} / \mathrm{dL})^{1}$ & $114 \pm 53$ & $106 \pm 32$ & 0.621 \\
Plasma metformin $(\mathrm{ng} / \mathrm{mL})^{2}$ & $300(225-412)$ & $551(278-645)$ & $\mathbf{0 . 0 3 8}$ \\
\hline SOD $\left(\mathrm{U}\right.$ SOD/g protein) ${ }^{2}$ & $-15.15(-30.20-11.40)$ & $8.24(-28.68-82.45)$ & 0.610 \\
\hline MDA $(\mu \mathrm{M})^{1}$ & $3.90 \pm 1.26$ & $2.64 \pm 0.67$ & $\mathbf{0 . 0 0 2}$ \\
\hline
\end{tabular}

HbA1c, glycohemoglobin; HDL, high-density lipoprotein; LDL, low-density lipoprotein; SOD, superoxide dismutase; MDA, malondialdehyde. 1 mean \pm standard deviation, independent t-test; ${ }^{2}$ median (interquartile range), Mann-Whitney $U$ test.

Table 3. Correlations between laboratory characteristics and oxidative stress parameters in 49 patients with type 2 diabetes mellitus on metformin (month 1). Vale do Sinos region and Metropolitan Area of Porto Alegre, state of Rio Grande do Sul, Brazil, 2010 to 2013.

\begin{tabular}{|c|c|c|}
\hline Laboratory blood parameters & $\begin{array}{l}\text { Superoxide dismutase } \\
\text { Correlation coefficient } \\
\text { ( } p \text { value) }\end{array}$ & $\begin{array}{c}\text { Malondialdehyde } \\
\text { Correlation coefficient } \\
\text { ( } p \text { value) }\end{array}$ \\
\hline HbA1c (\%) & $-0.128(0.450)^{1}$ & $0.376(0.008)^{1}$ \\
\hline Cholesterol (mg/dL) & $-0.032(0.852)^{2}$ & $0.234(0.106)^{2}$ \\
\hline HDL (mg/dL) & $-0.067(0.694)^{2}$ & $0.211(0.146)^{2}$ \\
\hline $\mathrm{LDL}(\mathrm{mg} / \mathrm{dL})$ & $0.159(0.355)^{2}$ & $0.048(0.747)^{2}$ \\
\hline Plasma metformin (ng/mL) & $-0.186(0.270)^{2}$ & $-0.310(0.030)^{2}$ \\
\hline SOD (U/g protein) & - & $-0.554(<0.001)^{2}$ \\
\hline
\end{tabular}

HbA1c, glycohemoglobin; HDL, high-density lipoprotein; LDL, low-density lipoprotein.

'Spearman's test; ${ }^{2}$ Pearson's test.

\section{DISCUSSION}

Increased oxidative stress was confirmed in the diabetic patients of this study, mainly through the positive correlation between glycemic control and MDA levels. The values of this biomarker were also increased compared to triglyceride levels, and decreased when compared to metformin plasma concentration. Reduction of MDA levels could also be observed when comparing the values before and after pharmacotherapeutic follow-up. Although no relationship between oxidative stress and the presence of adverse effects of metformin was found, there was a significant variation between blood glucose, HbA1c, plasma metformin, and MDA when patients with and without diabetic complications were compared.
The negative correlation between the amounts of SOD and MDA evidently shows that oxidative stress is present in diabetic patients, which is in line with the results of other studies [10, 26, 27]. Protein glycation is enhanced in diabetic patients, causing a drastic increase in superoxide production [28]. However, in this sample this increase did not generate an equivalent elevation in SOD3, probably due to a deficiency in the oxidation mechanism, which is characteristic of DM patients [29, 30]. Among other factors, this deficiency may be involved with single nucleotide polymorphisms related to antioxidant enzymes [31].

The positive correlation between glycemic control parameters and MDA in DM patients has been reported by other authors [32, 33], and it can be partially explained by the existing correlation 
between hyperglycemia and increased LPO [34]. The MDA molecule can also be generated as a byproduct of the synthesis of prostaglandins and thromboxanes [35, 36]. Furthermore, other mechanisms are suggested by Esterbauer et al. [37] based on the successive formation of hydroperoxides and on the breakdown of fatty acids, forming hydroperoxide aldehydes, subsequently generating the MDA molecule by beta-scission or by reaction of the acrolein radical with the hydroxyl radical.

Some studies have suggested increased oxidative stress, with equal increase in LPO, in normolipemic DM patients independently of the lipid profile [32]. The values found in this study are consistent with those described in other studies, in which no increase of MDA correlated with cholesterol, LDL, and HDL levels [38]. On the contrary, this biomarker was correlated with triglyceride levels. This is probably because MDA originates from the oxidation of unsaturated fatty acids [39], similar to the structure of the triglyceride molecule [40].

Although a relationship with SOD levels was not demonstrated, metformin plasma concentration showed a negative correlation with MDA levels, thereby suggesting a protective action against the effects of lipid peroxidation and, consequently, against oxidative stress. Metformin action has been mimicked by a combination of apocynin, a NADPH oxidase inhibitor, and thenoyltrifluoroacetone, an inhibitor of mitochondrial electron transport. This indicates that the antioxidant effect of metformin may be partly mediated by its effects on NADPH oxidase and on the mitochondria [16]. Other studies show the ability of metformin to inhibit glycation end products [41] and also to increase the expression of antioxidant thioredoxin peroxidase by activation of the AMPK-FOXO3 pathway [42].

Pharmacotherapeutic follow-up of DM patients has played a key role in increasing the survival rate and improving the quality of life of these patients, as the onset of diabetic complications is directly related to ineffective treatment and, consequently, to uncontrolled blood glucose levels [3, 13, 43].

No statistical difference in SOD levels was observed after pharmacotherapeutic follow-up; however, there was a small improvement in blood glucose, HbA1c, cholesterol, triglyceride, and LDL levels. The combination of these factors may have contributed to the significant decrease in MDA levels, suggesting a reduction of oxidative stress after the follow-up. Also, there was an increase in metformin plasma levels after pharmacotherapeutic follow-up, suggesting an improvement in the treatment of DM.
Patients who developed side effects to metformin showed no significant change in any of the analyzed parameters. This is probably because all adverse effects observed occurred in the gastrointestinal tract, owing to lower glucose absorption [44]. Moreover, no patients had lactic acidosis, which is considered the most severe adverse effect of metformin [45] and could have some influence on oxidative stress levels.

There was neither a significant difference in SOD regarding the number of diabetic complications, nor in the comparison of the groups with and without such complications. However, some studies have suggested that increased protein glycation leads to decreased vascular concentrations of SOD3, decreased intracellular SOD1 activity, and increased superoxide production. The sum of these effects tends to interfere with the balance of superoxide and nitric oxide in the blood vessels of diabetic patients and may play a role in the pathogenesis of peripheral vascular diseases associated with diabetes [46].

However, when dividing the study population by the presence or absence of diabetic complications, it was observed that blood glucose, $\mathrm{HbA} 1 \mathrm{c}$, and MDA levels increased significantly compared to the group without complications, while metformin plasma levels decreased. These factors are likely to be related, because the lowest concentration of metformin tends to worsen glycemic control and oxidative stress, and thus increases the chances of developing late diabetic complications [8].

MDA can also play an important role in late complications of diabetes due to the cross-linking of collagen, which contributes to the stiffening of the cardiovascular tissue. As a long-lived protein, this collagen stabilization reduces its correct operation, further enabling its glycation and oxidation. This, in turn, increases the potential of glycated collagen to start more fatty acid oxidations, releasing more MDA and, consequently, starting a positive feedback loop of damage to proteins and fatty acids [33].

MDA values also demonstrated a significant positive correlation with the number of diabetic complications per patient, confirming findings that relate the degree of complications to the accumulation of LPO products $[47,48]$.

By analyzing the data found in this study, it can be concluded that oxidative stress in diabetic patients is even more pronounced in those who have worse glycemic control and diabetic complications. The multifactorial nature of this disorder and the interrelationship between DM-related biochemical parameters was also reinforced, thus emphasizing the 
importance of controlling these factors to prevent, delay, and/or reduce the development of late complications of diabetes. This control may be mediated by the antioxidant action of metformin and enhanced with the pharmacotherapeutic follow-up of this group of patients. However, due to the presence of controversial data on the activity of antioxidant enzymes in DM, there is the need for long-term prospective studies in order to analyze a large number of parameters and elucidate the mechanisms involved in the complex pathophysiology of DM2.

\section{NOTES}

\section{Financial support}

This study received a grant from the Brazilian National Council of Scientific and Technological Development (CNPq), and financial support from Feevale University.

\section{Conflicts of interest disclosure}

The authors declare no competing interests relevant to the content of this study. They claim to have had full access to all available data and they take full responsibility for the integrity of the results described herein.

\section{REFERENCES}

1. Milech A, Oliveira JEP, Vencio S, organizadores. Diretrizes da Sociedade Brasileira de Diabetes (2015-2016). São Paulo: A.C. Farmacêutica; 2016.

2. Shaw JE, Sicree RA, Zimmet PZ. Global estimates of the prevalence of diabetes for 2010 and 2030. Diabetes Res Clin Pract. 2010;87(1):4-14. https://doi.org/10.1016/j.diabres.2009.10.007

3. Kassahun T, Eshetie T, Gesesew, H. Factors associated with glycemic control among adult patients with type 2 diabetes mellitus: a cross-sectional survey in Ethiopia. BMC Res Notes. 2016 Feb 9;9:78. https://doi.org/10.1186/s13104-016-1896-7

4. Murthy G, Das T. Diabetic care initiatives to prevent blindness from diabetic retinopathy in India. Indian J Ophthalmol. 2016 Jan;64(1):50-4. https://doi.org/10.4103/0301-4738.178152

5. Sociedade Brasileira de Endocrinologia e Metabologia. SBEM. Projeto Diretrizes, Diabetes Mellitus, Prevenção. Rio de Janeiro: SBEM; 2006.

6. Ali A, Iqbal F, Taj A, Iqbal Z, Amin MJ, Iqbal QZ. Prevalence of microvascular complications in newly diagnosed patients with Type 2 diabetes. Pak J Med Sci. 2013 July;29(4):899-902. https://doi.org/10.12669/pjms.294.3704

7. Molyneaux LM, Constantino MI, Mcgill M, Zilkens R, Yue DK. Better glycaemic control and risk reduction of diabetic complications in Type 2 diabetes: comparison with the DCCT. Diabetes Res Clin Pract. 1998 Nov;42(2):77-83. https://doi.org/10.1016/S01688227(98)00095-3

8. Tapp RJ, Zimmet PZ, Harper CA, De Courten MP, Mccarty DJ, Balkau B, Taylor HR, Welborn TA, Shaw JE, Aus Diab Study Group. Diagnostic thresholds for diabetes: the association of retinopathy and albuminuria with glycaemia. Diabetes Res Clin Pract. 2006;73(3):315-21. https://doi.org/10.1016/j.diabres.2006.02.008

9. Daroux M, Prevost G, Maillard-Lefebvre H, Gaxatte C, D'agati VD, Schmidt AM, Boulanger G. Advanced glycation endproducts: implications for diabetic and non-diabetic nephropathies. Diabetes Metab. 2010 Feb;36(1):1-10. https://doi.org/10.1016/j. diabet.2009.06.005

10. Ziegler D, Sohr CG, Nourooz-Zadeh J. Oxidative stress and antioxidant defense in relation to the severity of diabetic polyneuropathy and cardiovascular autonomic neuropathy. Diabetes Care. 2004 Sept;27(9):2178-83. https://doi.org/10.2337/diacare.27.9.2178

11. Tschiedel B. Complicações crônicas do diabetes. JBM. 2014;102(5):7-12.

12. Filla LA, Edwards JL. Metabolomics in diabetic complications. Mol Biosyst. 2016 Apr;12(4):1090-105. https://doi.org/10.1039/ C6MB00014B

13. Ray KK, Seshasa ISR, Wijesuriya S, Sivakumaran R, Nethercott S, Preiss D, Erqou S, Sattar N. Effect of intensive control of glucose on cardiovascular outcomes and death in patients with diabetes mellitus: a meta-analysis of randomised controlled trials. Lancet. 2009;373(9677):1765-72. https://doi.org/10.1016/S0140-6736(09)60697-8

14. Shen GX. Oxidative stress and diabetic cardiovascular disorders: roles of mitochondria and NADPH oxidase. Can J Physiol Pharmacol. 2010;88(3):241-8. https://doi.org/10.1139/Y10-018

15. Brownlee M. The pathobiology of diabetic complications: a unifying mechanism. Diabetes. 2005;54(6):1615-25. https://doi. org/10.2337/diabetes.54.6.1615

16. Bellin C, Wiza DH, Wiernsperger NF, Rösen P. Generation of reactive oxygen species by endothelial and smooth muscle cells: influence of hyperglycemia and metformin. Horm Metab Res. 2006 Nov;38(11):732-9. https://doi.org/10.1055/s-2006-955084

17. Reis JS, Veloso CA, Mattos RT, Purish S, Nogueira-Machado JA. Estresse oxidativo: revisão da sinalização metabólica no diabetes tipo 1. Arq Bras Endocrinol. 2008;52(7):1096-105. https://doi.org/10.1590/s0004-27302008000700005

18. Halliwell B. Free radicals and vascular disease: how much do we know? BMJ. 1993 Oct 9;307(6909):885-6. https://doi.org/10.1136/ bmj.307.6909.885

19. Marklund SL. Human copper-containing superoxide dismutase of high molecular weight. Proc Natl Acad Sci. 1982;79(24):7634-8. https://doi.org/10.1073/pnas.79.24.7634 
20. Ookawara T, Eguchi H, Nishimura M, Kizaki T, Eiji Takayama, Saitoh D, Ohno H, Suzuki K. Effects of oxidative stress on the nuclear translocation of extracellular superoxide dismutase. Biochem Biophys Res Commun. 2003 Apr 11;303(3):914-9. https://doi. org/10.1016/S0006-291X(03)00441-8

21. Benzie IF. Lipid peroxidation: a review of causes, consequences, measurement and dietary influences. Int J Food Sci Nutr. 1996;47(3):233-61. https://doi.org/10.3109/09637489609012586

22. Lima ES, Abdalla DSP. Peroxidação lipídica: mecanismos e avaliação em amostras biológicas. Rev Bras Cien Farm. 2001;37(3):1-11.

23. Marnett LJ. Lipid peroxidation-DNA damage by malondialdehyde. Mutat Res. 1999;424(1-2):83-95. https://doi.org/10.1016/S00275107(99)00010-X

24. Antunes MV, Lazzaretti C, Gamaro GD, Linden R. Estudo pré-analítico e de validação para determinação de malondialdeído em plasma humano por cromatografia líquida de alta eficiência, após derivatização com 2,4-dinitrofenilhidrazina. Rev Bras Cien Farm. 2008;44:279-87. https://doi.org/10.1590/S1516-93322008000200013

25. Antunes MV, Wagner SC, Camargo JL, Linden R. Standardization of method for determining glycosylated hemoglobin (Hb A1c) by cation exchange high performance liquid chromatography. Braz J Pharm. 2009;45(4):650-7. https://doi.org/10.1590/S198482502009000400007

26. Kuyvenhoven JP, Meinders AE. Oxidative stress and diabetes mellitus: Pathogenesis of long-term complications. Eur J Intern Med. 1999;10(1):9-19. https://doi.org/10.1016/S0953-6205(99)00009-6

27. Soliman GZA. Blood lipid peroxidation (superoxide dismutase, malondialdehyde, glutathione) levels in Egyptian type 2 diabetic patients. Singapore Med J. 2008 Feb;49(2):129-36.

28. Mullarkey CJ, Edelstein D, Brownlee M. Free radical generation by early glycation products: a mechanism for accelerated atherogenesis in diabetes. Biochem Biophys Res Commun. 1990;173(3):932-9. https://doi.org/10.1016/S0006-291X(05)80875-7

29. Bhatia S, Shukla R, Madhu SV, Gambhir JK, Prabhu KM. Antioxidant status, lipid peroxidation and nitric oxide end products in patients of type 2 diabetes mellitus with nephropathy. Clin Biochem. 2003 Oct;36(7):557-62. https://doi.org/10.1016/S0009-9120(03)00094-8

30. Rahimi R, Nikfar S, Larijani B, Abdollahi M. A review on the role of antioxidants in the management of diabetes and its complications. Biomed Pharmacother. 2005 Aug;59(7):365-73. https://doi.org/10.1016/j.biopha.2005.07.002

31. Flekac M, Skrha J, Hilgertova J, Lacinova Z, Jarolimkova M. Gene polymorphisms of superoxide dismutases and catalase in diabetes mellitus. BMC Med Genet. 2008 Apr 21;9:30. https://doi.org/10.1186/1471-2350-9-30

32. Freitas JP, Filipe PM, Rodrigo FG. Lipid peroxidation in type 2 normolipidemic diabetic patients. Diabetes Res Clin Pract. 1997 May;36(2):71-5. https://doi.org/10.1016/S0168-8227(97)00032-6

33. Slatter DA, Bolton CH, Bailey AJ. The importance of lipid-derived malondialdehyde in diabetes mellitus. Diabetologia. 2000 May;43(5):550-7. https://doi.org/10.1007/s001250051342

34. Davi G, Ciabattoni G, Consoli A, Mezzetti A, Falco A, Santarone S, Pennese E, Vitacolonna E, Bucciarell T, Costantini F, Capani F, Patrono C. In vivo formation of 8-iso-prostaglandin f2alpha and platelet activation in diabetes mellitus: effects of improved metabolic control and vitamin E supplementation. Circulation. 1999;99(2):224-9. https://doi.org/10.1161/01.CIR.99.2.224

35. Hecker M, Ullrich V. On the mechanism of prostacyclin and thromboxane A2 biosynthesis. J Biol Chem. 1989;264(1):141-50.

36. Kume S, Takeya M, Mori T, Araki N, Suzuki H, Horiuchi S, Kodama T, Miyauchi Y, Takahashi K. Immunohistochemical and ultrastructural detection of advanced glycation end products in atherosclerotic lesions of human aorta with a novel specific monoclonal antibody. Am J Pathol. 1995;147(3):654-67.

37. Esterbauer H, Schaur RJ, Zollner H. Chemistry and biochemistry of 4-hydroxynonenal, malonaldehyde and related aldehydes. Free Radic Biol Med. 1991;11(1):81-128. https://doi.org/10.1016/0891-5849(91)90192-6

38. Dyer RG, Stewart MW, Mitcheson J, George K, Alberti MM, Laker MF. 7-ketocholesterol, a specific indicator of lipoprotein oxidation, and malondialdehyde in non-insulin dependent diabetes and peripheral vascular disease. Clin Chim Acta. 1997;260(1):1-13. https:// doi.org/10.1016/S0009-8981(96)06499-6

39. Kesavulu MM, Rao BK, Giri R, Vijaya J, Subramanyam G, Apparao C. Lipid peroxidation and antioxidant enzyme status in Type 2 diabetics with coronary heart disease. Diabetes Res Clin Pract. 2001;53(1):33-9. https://doi.org/10.1016/S0168-8227(01)00238-8

40. Lehner R, Kuksis A. Biosynthesis of triacylglycerols. Prog Lipid Res. 1996;35(2):169-201. https://doi.org/10.1016/0163-7827(96)00005-7

41. Beisswenger P, Ruggiero-Lopez D. Metformin inhibition of glycation processes. Diabetes Metab. 2003;29(4 Pt 2):6S95-103.

42. Hou X, Song J, Li XN, Zhang L, Wang X, Chen L, Shen YH. Metformin reduces intracellular reactive oxygen species levels by upregulating expression of the antioxidant thioredoxin via the AMPK-FOXO3 pathway. Biochem Biophys Res Commun. 2010 May 28;396(2):199-205. https://doi.org/10.1016/j.bbrc.2010.04.017

43. Lang VB, Marković BB. Prevalence of comorbidity in primary care patients with type 2 diabetes and its association with elevated HbA1c: A cross-sectional study in Croatia. Scand J Prim Health. 2016;34(1):66-72. https://doi.org/10.3109/02813432.2015.1132886

44. Rovaris DL, Grohe R, Santos B, Perassolo MS, De Andrade FM. Metformina e Diabetes Melito Tipo 2: Passado, Presente e Farmacogética. Rev HCPA. 2010;30(4):382-90.

45. Bouchoucha M, Uzzan B, Cohen R. Metformin and digestive disorders. Diabetes Metab. 2011;37(2):90-6. https://doi.org/10.1016/j. diabet.2010.11.002

46. Fattman CL, Schaefer LM, Oury TD. Extracellular superoxide dismutase in biology and medicine. Free Radic Bio Med. 2003;35(3): 253-6. https://doi.org/10.1016/S0891-5849(03)00275-2

47. Palanduz S, Ademoğlu E, Gökkuşu C, Tamer S. Plasma antioxidants and type 2 diabetes mellitus. Res Commun Mol Pathol Pharmacol. 2001;109(5-6):309-18.

48. Pan HZ, Zhang H, Chang D, Li H, Sui H. The change of oxidative stress products in diabetes mellitus and diabetic retinopathy. Brit J Ophthalmol. 2008;92(4):548-51. https://doi.org/10.1136/bjo.2007.130542 C 